DOI: 10.20472/IAC.2017.034.048

MARLON ROJAS

INSTITUTO POLITECNICO NACIONAL, Mexico

LESLIE ARCILA

INSTITUTO POLITECNICO NACIONAL, MeXico

ANTONIETA RIOS

INSTITUTO POLITECNICO NACIONAL, Mexico

ABDU ORDUÑA

INSTITUTO POLITECNICO NACIONAL, MeXico

VALENTIN LOPEZ

INSTITUTO POLITECNICO NACIONAL, Mexico

ORLANDO ZACA

INSTITUTO POLITECNICO NACIONAL, Mexico

GERARDO MUÑOZ

INSTITUTO POLITECNICO NACIONAL, MeXico

\title{
GOLD NANOPARTICLES ON THE DEVELOPMENT OF FLUORESCENT BIOSENSORS FOR THE DETECTION OF PATHOGENIC BACTERIA IN WATER AND FOODS
}

\begin{abstract}
:
Actually the use of biosensors for the diagnostic of infectious diseases has attracted considerably the attention due to the feasibility that offer by their qualities such as the time of response, specificity and sensitivity, as well as low cost. In particular the biosensors made from gold nanoparticles could offer these advantages, for the detection of a large number of analytes. This research show a simple methodology to prepare fluorescent biosensors for the rapid detection of pathogens in foods and water using a bioconjugate based on gold nanoparticles. The efficiency on the detection of the bacteria Salmonella sp. and Staphylococcus aureus in samples of water and contaminated milk was proved. The proposed methodology could represent a viable alternative for applications in the field of rapid diagnosis of infectious diseases.
\end{abstract}

\section{Keywords:}

Biosensors, nanoparticles, pathogens, Salmonella sp., Staphylococcus aureus.

JEL Classification: $L 65,111,113$ 